\title{
TEKNIK PEMBIBITAN KAYU PUTIH (MELALUCA CAJUPUTI) SECARA VEGETATIF DI PERSEMAIAN PERUSAHAAN BATUBARA PT BUKIT ASAM (PERSERO) TBK
}

\author{
Breeding Techniques of Melalueca cajuputi in Vegetative at Nurseries Coal Company \\ PT Bukit Asam Ltd
}

Irdika Mansur $^{1^{*}}$ dan Muhd Indarwan Kadaraisman ${ }^{2}$

(Diterima April 2017/Disetujui Februari 2019)

\begin{abstract}
Melaleuca cajuputi has an ability to sprout easily, this is one of indicator for plants that potentially could be reproduced productively. PT Bukit Asam Ltd. has used Melaleuca cajuputi as the main of tree species for the reclamation of its post-mining land. The seedlings are produced generatively using seeds. The purpose of this research was to determine responses of IBA and Growth Media on the tip cutting of Melaleuca cajuputi The results showed that $88.9 \%$ of the cuttings, $61.2 \%$ of the rooted, and $80.9 \%$ of the shoots were viable. The used of IBA and a variety of growing media did not significantly affect to life percentage, rooted percentage, shoots percentage, fresh weight and dry weight of root, fresh weight and dry weight of shoots, numbers of primary and secondary roots, length of primary roots, and length of shoots. The result of this research can be adopted by PT Bukit Asam Ltd. to shorten production time of Melaleuca cajuputi seedlings in the future, where the availability of seeds is limited.
\end{abstract}

Key words: IBA, Melaleuca cajuputi, cutting, mining

\section{PENDAHULUAN}

Upaya reklamasi pada lahan bekas tambang terus dilakukan, sebagaimana peraturan pemerintah No 76 tahun 2008 tentang Rehabilitasi dan Reklamasi Hutan. Salah satu prospek reklamasi pada lahan bekas tambang ialah pembangunan hutan tanaman. Kayu putih (Melaleuca cajuputi) dapat tumbuh di lahan marginal dan merupakan jenis yang potensial untuk tanaman reklamasi lahan bekas tambang, baik dari segi ekologis maupun dari segi ekonomi (Kartikawati dan Rimbawanto 2010). Secara ekologis kayu putih merupakan spesies lokal di Sumatera dan mampu bertahan hidup di lahan-lahan kritis. Kayu putih juga dapat menunjang usaha koservasi lahan dan pemanfaatan lahan marjinal. Secara ekonomi, daun kayu putih dimanfatkan untuk produksi minyak kayu putih. PT Bukit Asam (Persero), Tbk telah melakukan produksi penyulingan minyak kayu putih.

Menurut informasi industri pengepakan minyak kayu putih dalam Kartikawati dan Rimbawanto (2010), kebutuhan terhadap permintaan kayu putih dalam negeri sebesar 1500 ton per tahun, sementara itu suplai tahunanya hanya sebesar 400 ton per tahun. Hal ini mengindikasikan bahwa sebenarnya peluang untuk pengembangan industri minyak kayu putih masih terbuka lebar.

Perbanyakan tanaman dengan benih memerlukan waktu lama, sehingga upaya untuk mengembangkan

\footnotetext{
${ }^{1}$ Staff Pengajar Dept. Silvikultur, Fakultas Kehutanan IPB

* Penulis korespondensi: e-mail:

${ }^{2}$ Mahasiswa Dept. Silvikultur, Fakultas Kehutanan IPB
}

teknik pembiakan vegetatif yang lebih efektif perlu diupayakan, mengingat stek pucuk memiliki keunggulan dalam memanfaatkan seluruh potensi genetik yang ada pada tanaman dibandingkan dengan pembiakan generatif melalui benih (Kartikawati dan Rimbawanto 2010). Komposisi media tanam dan penggunaan Zat Pengatur Tumbuh (ZPT) mempengaruhi keberhasilan stek, sehingga perlu dilakukan penelitian stek pucuk kayu putih dengan komposisi media tanam tanah, pasir, arang sekam dan pasir dengan kombinasi Zat Pengatur Tumbuh IBA (Indole Butyric Acid) untuk mendapatkan perlakuan terbaik dalam mendukung pertumbuhan stek pucuk kayu putih.

\section{BAHAN DAN METODE}

\section{Waktu dan Tempat Penelitian}

Penelitian dilaksanakan selama 6 minggu yang bertempat di Persemaian Satuan Kerja Pengelolaan Lingkungan PT Bukit Asam (Persero), Tbk. Tanjung Enim Sumatera Selatan.

\section{Bahan dan Alat}

Bahan yang digunakan untuk penelitian antara lain polybag ukuran 10x15 cm, IBA sebagai Zat Pengatur Tumbuh, aquades, tanah hutan horison $\mathrm{O}$, arang sekam, pasir, dan bibit kayu putih berumur 4 bulan (tinggi 50 $\mathrm{cm}-60 \mathrm{~cm}$, diameter $0.5 \mathrm{~cm}$ ) di persemaian PT Bukit Asam (Persero), Tbk. Alat yang digunakan antara lain cutter, kompor gas, tong, hand sprayer, ember, wajan, serokan, pipet serologi, alat penyaring, baki, plastik bening, penggaris, gunting, tally sheet, timbangan digital, karet ban bekas, kamera digital, dan alat tulis. 


\section{Metode kerja}

Tahapan penelitian yang dilakukan adalah sebagai berikut:

\section{Persiapan sungkup}

Sungkup dibuat menggunakan baki plastik ukuran 40x25×15 cm sebanyak 12 buah baki, dan ditutup dengan menggunakan plastik bening yang diikat dengan menggunakan karet ban bekas.

\section{Persiapan media tanam}

Media tanam yang digunakan pada penelitian ini yaitu tanah, pasir, serta arang sekam dan pasir $(1: 2, \mathrm{v} / \mathrm{v})$. Masing-masing media tersebut disterilisasi terlebih dahulu. Pasir disangrai dengan cara dimasukkan dalam wajan dan diaduk selama sekitar 20 menit, tanah dikeringkan terlebih dahulu selama 48 jam, dan sekam dibakar terlebih dahulu dengan dimasukan ke dalam tong sehingga menjadi arang sekam. Masing-masing media tersebut kemudian didinginkan atau diaklimatisasi selama 24 jam. Setelah itu dimasukkan ke dalam polybag yang sebelumnya telah ditandai sesuai dengan tata letak percobaan.

\section{Penyiapan ZPT}

ZPT yang digunakan yaitu IBA konsentrasi $0 \mathrm{ppm}$, 500 ppm, dan 1500 ppm. IBA sebelumnya telah dilarutkan dengan $\mathrm{NaOH} 1 \%$ lalu dicampurkan ke dalam aquades sebanyak satu liter.

\section{Penyiapan bahan stek}

Teknik perbanyakan dengan stek pucuk pada kayu putih dilakukan dengan memanfaatkan tunas-tunas muda, yaitu bagian pucuk pada kayu putih. Bibit yang telah dipilih selanjutnya dipotong di bagian pucuk dengan dengan menggunakan gunting stek dengan panjang $5-7 \mathrm{~cm}$. Bagian pangkal stek dipotong miring $45^{\circ}$, dan menyisakan 2-3 helai daun. Daun yang disisakan tersebut selanjutnya dipotong dan disisakan sepertiga bagian untuk mengurangi trasnpirasi pada bahan stek.

\section{Penanaman stek}

Penanaman stek pucuk dilakukan pada pagi hari, yaitu sekitar jam 07.00-09.00. Media tanam dilubangi terlebih dahulu mencapai kedalaman $\pm 3 \mathrm{~cm}$ sebelum dilakukan penanaman untuk menghindari pelukaan bahan stek khususnya bagian pangkal. Setelah stek ditanam, lubang ditutup kembali agar stek dapat tertanam dengan baik dan berdiri tegak. Kemudian baki sebagai wadah penanaman ditutup rapat dengan plastik bening.

\section{Pemeliharaan}

Pemeliharaan dilakukan berkala setiap hari selama waktu pengamatan yaitu dengan penyiraman dan pengendalian hama penyakit pada stek pucuk kayu putih. Penyiraman disesuaikan dengan kondisi media, dan biasa dilakukan pada pagi hari jam 08.00-09.00 atau sore hari jam 16.00-17.00.

\section{Pengamatan dan pengambilan data}

Parameter yang diamati yaitu persentase hidup, persentase berakar, persentase bertunas, berat basah akar, berat kering akar, berat basah tunas, berat kering tunas, jumlah akar primer, jumlah akar sekunder, panjang akar primer, dan panjang tunas.

\section{a. Persentase hidup}

Persentase hidup $=\frac{\text { Jumlah stek yang bertahan }}{\text { Jumlah stek yang ditanam }} \times 100 \%$

\section{b. Persentase berakar}

Persentase berakar $=\frac{\text { Jumlah stek yang berakar }}{\text { Jumlah stek yang ditanam }} \times 100 \%$

\section{c. Persentase bertunas}

Persentase bertunas $=\frac{\text { Jumlah stek yang bertunas }}{\text { Jumlah stek yang ditanam }} \times 100 \%$

d. Berat basah akar dihitung pada akhir pengamatan, dengan memotong bagian akar yang tumbuh pada stek, kemudian ditimbang dalam kondisi basah dengan menggunakan timbangan digital.

e. Berat kering akar dihitung dengan mengoven akar pada setiap stek selama 24 jam pada suhu $70^{\circ} \mathrm{C}$, kemudian ditimbang dengan menggunakan timbangan digital. Pemilihan suhu $70^{\circ} \mathrm{C}$ agar kandungan nitrogen tidak menguap (Supriyanto dan Prakarsa 2011).

f. Berat basah tunas dihitung pada akhir pengamatan, dengan memotong bagian tunas yang tumbuh pada stek, kemudian ditimbang dalam kondisi basah dengan menggunakan timbangan digital.

g. Berat kering tunas dihitung dengan mengoven tunas pada setiap stek selama 24 jam pada suhu $70^{\circ}$ $\mathrm{C}$, kemudian ditimbang dengan menggunakan timbangan digital.

h. Jumlah akar primer dihitung manual diakhir pengamatan. Akar primer merupakan akar yang berkembang dari radikula (akar utama yang tumbuh dari biji).

i. Jumlah akar sekunder dihitung manual diakhir pengamatan. Akar sekunder biasanya berbentuk serabut halus yang menempel pada akar primer.

j. Panjang akar primer dihitung dari stek yang berakar dengan menggunakan penggaris dari pangkal akar sampai ujung terpanjang akar primer.

k. Panjang tunas dihitung dari stek yang bertunas dengan menggunakan penggaris dari pangkal tunas sampai ujung terpanjang tunas.

\section{Rancangan Percobaan}

Rancangan percobaan menggunakan Rancangan Acak Lengkap (RAL) faktorial dengan dua faktor dan ulangan sebanyak 6 kali (Tabel 1). Jumlah unit ulangan ialah 3, sehingga jumlah seluruh kombinasi perlakuan

Tabel 1 Kombinasi perlakuan pada rancangan acak lengkap faktorial stek pucuk kayu putih (Melaleuca cajuputi)

\begin{tabular}{lccc}
\hline \multirow{2}{*}{ Perlakuan ZPT } & \multicolumn{3}{c}{ Perlakuan media tanam } \\
\cline { 2 - 4 } & $\mathrm{B}_{1}$ & $\mathrm{~B}_{2}$ & $\mathrm{~B}_{3}$ \\
\hline $\mathrm{A}_{1}$ & $\mathrm{~A}_{1} \mathrm{~B}_{1}$ & $\mathrm{~A}_{1} \mathrm{~B}_{2}$ & $\mathrm{~A}_{1} \mathrm{~B}_{3}$ \\
$\mathrm{~A}_{2}$ & $\mathrm{~A}_{2} \mathrm{~B}_{1}$ & $\mathrm{~A}_{2} \mathrm{~B}_{2}$ & $\mathrm{~A}_{2} \mathrm{~B}_{3}$ \\
$\mathrm{~A}_{3}$ & $\mathrm{~A}_{3} \mathrm{~B}_{1}$ & $\mathrm{~A}_{3} \mathrm{~B}_{2}$ & $\mathrm{~A}_{3} \mathrm{~B}_{3}$ \\
\hline
\end{tabular}


sebanyak 162 bahan vegetatif. Faktor penelitian tersebut antara lain: faktor jenis Zat Pengatur Tumbuh (A), dan faktor jenis media tanam (B), yang terdiri dari tiga taraf: $\mathrm{A}_{1}=$ IBA 0 ppm, $\mathrm{A}_{2}=$ IBA $500 \mathrm{ppm}, \mathrm{A}_{3}=$ IBA 1500 ppm, $\mathrm{B}_{1}=$ Tanah, $\mathrm{B}_{2}=$ Pasir dan $\mathrm{B}_{3}=$ Arang sekam dan pasir $(1: 2, \mathrm{v} / \mathrm{v})$.

Data yang diperoleh dari hasil pengamatan akhir pada saat panen kemudian diolah dan dianalisis dengan menggunakan sidik ragam. Model linier aditif dari rancangan ini menurut Matjik dan Sumertajaya (2006) adalah:

$$
\text { Yijk }=\mu+\alpha i+\beta j+(\alpha \beta) i j+\sum i j k
$$

Ket:

Yijk = Respon dari pengamatan faktor jenis ke A (ZPT) taraf ke-i faktor jenis B (media tanam) taraf ke-j dan ulangan ke-k

$\mu \quad=$ Nilai rata-rata pengamatan

$\alpha \mathrm{i}=$ Pengaruh perlakuan ZPT IBA taraf ke-i

$\beta \mathrm{j}=$ Pengaruh perlakuan media tanam taraf ke-j

$(\alpha \beta)$ ij $=$ Pengaruh interaksi konsentrasi ZPT IBA taraf ke-i dengan media tanam pada taraf ke-j

Eijk = Pengaruh acak faktor jenis ZPT IBA taraf kei dengan faktor jenis media tanam taraf ke-j dan ulangan ke-k

$\mathrm{I}=1,2,3$

$\mathrm{J}=1,2,3$

$\mathrm{K}=1,2,3,4,5$, dan 6

\section{Analisa data}

Tabel 2 Rekapitulasi hasil sidik ragam pengaruh pemberian Zat Pengatur Tumbuh (ZPT) dan media tanam terhadap pertumbuhan stek pucuk kayu putih (Melaleuca cajuputi) umur 4 bulan

\begin{tabular}{|c|c|c|c|}
\hline \multirow[b]{2}{*}{ Parameter } & \multicolumn{2}{|c|}{ Sumber Keragaman } & \multirow{2}{*}{$\begin{array}{c}\text { Interaksi } \\
\text { Bahan } \\
\text { dan ZPT }\end{array}$} \\
\hline & Bahan & $\begin{array}{c}\text { Konsentrasi } \\
\text { ZPT }\end{array}$ & \\
\hline (1) & (2) & (3) & (4) \\
\hline \% Hidup" & tn & tn & $\operatorname{tn}$ \\
\hline \% Berakar" & tn & tn & tn \\
\hline$\%$ Bertunas" & tn & $\operatorname{tn}$ & $\operatorname{tn}$ \\
\hline Berat basah akar & tn & tn & $\operatorname{tn}$ \\
\hline Berat basah tunas & tn & tn & $\operatorname{tn}$ \\
\hline Berat kering akar & tn & tn & tn \\
\hline Berat kering tunas & tn & tn & $\operatorname{tn}$ \\
\hline Jumlah akar primer & tn & tn & $\operatorname{tn}$ \\
\hline $\begin{array}{l}\text { Jumlah akar } \\
\text { sekunder }\end{array}$ & tn & tn & $\operatorname{tn}$ \\
\hline $\begin{array}{l}\text { Panjang akar } \\
\text { primer }\end{array}$ & tn & tn & $\operatorname{tn}$ \\
\hline Panjang tunas & tn & tn & tn \\
\hline
\end{tabular}

Data yang diperoleh diolah dengan menggunakan Microsoft office Excel dan STAR. Analisis sidik ragam menggunakan uji $\mathrm{F}$ terhadap variabel yang diamati untuk mengetahui pengaruh interaksi antara berbagai perlakuan yang diberikan. Jika P-value $>\alpha(0.05)$, maka perlakuan tidak memberikan pengaruh nyata terhadap variabel yang diamati, dan jika P-value $<\alpha(0.05)$, maka perlakuan memberikan pengaruh nyata terhadap variabel yang diamati. Uji lanjut wilayah berganda Duncan dilakukan apabila hasil sidik ragam menyatakan bahwa perlakuan memberikan pengaruh nyata.

\section{HASIL DAN PEMBAHASAN}

\section{Hasil Stek Kayu Putih}

Hasil analisis sidik ragam pengaruh pemberian ZPT dan jenis media tanam terhadap petumbuhan stek pucuk kayu putih dapat dilihat pada Tabel 2 .

Stek pucuk merupakan teknik perbanyakan tanaman dengan terlebih dahulu menumbuhkan tunas-tunas aksilar hingga tunas tersebut berakar sebelum ditanam di lapangan (Nababan 2009). Konsentrasi ZPT dan jenis media tanam tidak memberikan pengaruh nyata, baik secara tunggal maupun interaksi keduanya terhadap semua parameter yang diamati yaitu: persentase hidup, persentase berakar, persentase bertunas, berat basah akar, berat kering akar, berat basah tunas, berat kering tunas, jumlah akar primer, jumlah akar sekunder, panjang akar primer, dan panjang tunas.

\section{Persentase Hidup, Persentase Berakar, dan Persentase Bertunas}

Persentase hidup stek pucuk kayu putih mencapai $88.9 \%$ atau sebanyak 144 stek dari total 162 bahan stek. Stek pucuk dikatakan hidup ditunjukkan dengan bahan stek yang berwarna hijau segar dan berdiri kokoh pada media tanam (Demastiti 2015, Fitria 2015).

Tabel 3 Pengaruh Zat Pengatur Tumbuh (ZPT) terhadap persentase hidup, persentase berakar, dan persentase bertunas dari stek pucuk kayu putih (Melaleuca cajuputi) umur 4 bulan

\begin{tabular}{lccc}
\hline & \multicolumn{3}{c}{ Parameter } \\
\cline { 2 - 4 } Perlakuan ZPT & $\begin{array}{c}\% \\
\text { hidup }\end{array}$ & $\begin{array}{c}\% \\
\text { berakar }\end{array}$ & bertunas \\
\hline $\mathrm{A}_{1}$ (IBA 0 ppm) & 94.4 & 66.7 & 83.3 \\
$\mathrm{~A}_{2}$ (IBA 500 ppm) & 81.5 & 57.4 & 74.1 \\
$\mathrm{~A}_{3}$ (IBA 1500 ppm) & 90.7 & 59.3 & 85.4 \\
\hline
\end{tabular}

Tabel 4 Pengaruh media tanam terhadap persentase hidup, persentase berakar, dan persentase bertunas dari stek pucuk kayu putih (Melaleuca cajuputi) umur 4 bulan

\begin{tabular}{lccc}
\hline \multirow{2}{*}{$\begin{array}{l}\text { Perlakuan media } \\
\text { tanam }\end{array}$} & $\begin{array}{c}\% \\
\text { Pidup }\end{array}$ & $\begin{array}{c}\% \\
\text { berakar }\end{array}$ & $\begin{array}{c}\% \\
\text { bertunas }\end{array}$ \\
\cline { 2 - 4 } $\mathrm{A}_{1}$ (IBA 0 ppm) & 87.0 & 59.3 & 81.7 \\
$\mathrm{~A}_{2}$ (IBA 500 ppm) & 90.7 & 63.0 & 81.5 \\
$\mathrm{~A}_{3}$ (IBA 1500 ppm) & 88.9 & 61.1 & 79.6 \\
\hline
\end{tabular}


Pengaruh ZPT dan pengaruh media tanam terhadap persentase hidup, persentase berakar, dan persentase bertunas masing-masing perlakuan dapat dilihat pada Tabel 3 dan Tabel 4.

Stek kayu putih rata-rata memiliki pertumbuhan yang baik, pada minggu kedua penanaman belum ditemukan tanaman yang mati. Pengamatan pada pekan ke tiga ditemukan 10 tanaman yang mati dari total seluruh bahan stek. Perlakuan ZPT dan media tanam tidak memberikan pengaruh nyata, baik secara tunggal maupun interaksi keduanya pada persentase hidup stek Hal ini diduga karena bahan stek pucuk kayu putih yang digunakan adalah sama (umur, tinggi, dan diamater), sehingga kemampuan tumbuh dalam waktu 6 minggu masih terlihat sama.

Tujuan pemberian hormon auksin (IBA) adalah untuk meningkatkan persentase stek yang berakar, mempercepat pertumbuhan akar, meningkatkan jumlah dan kualitas akar, serta untuk menyeragamkan munculnya akar (Aminah 2002, Harjadi dan Setyati 2009). Konsentrasi hormon yang diberikan juga dipengaruhi oleh jenis tanaman, umur bahan stek, lama pemberian hormon, media yang digunakan, dan umur bahan stek (Priadjati dan Tolkamp 2002). Persentase hidup pada perlakuan IBA 0 ppm, IBA 500 ppm, dan IBA 1500 ppm berturut-turut adalah adalah 94.4\%, $81.5 \%$, dan $90.7 \%$, sedangkan pada perlakuan media tanam tanah, pasir, serta pasir dan arang sekam didapatkan persentse hidup berturut-turut adalah $87.0 \%$, $90.7 \%$, dan $88.9 \%$.

Munculnya akar merupakan indikator kemampuan stek untuk dapat bertahan hidup (Nurzaman 2005). Persentase berakar pada perlakuan IBA 0 ppm, IBA 500 ppm, dan IBA 1500 ppm berturut-turut ialah $66.7 \%$, $57.4 \%$, dan $59.3 \%$. Hasil yang sama ditunjukkan oleh perlakuan berbagai jenis media tanam tanah, pasir, pasir dan arang sekam juga tidak berbeda secara signifikan, dengan nilai beruturut-turut adalah $59.3 \%, 63.0 \%$, dan $61.1 \%$. Rentang nilai persentase berakar masing-masing perlakuan tidak memperlihatkan perbedaan yang signifikan. Persentase berakar secara keseluruhan ialah $61.2 \%$ atau sebanyak 98 stek dari total bahan stek yang ditanam dan sisanya sebanyak 46 stek tetap hidup. Walaupun tidak berakar stek masih menunjukkan pertumbuhan sampai akhir pengamatan dan stek yang tidak berakar membentuk kalus. Hal ini sesuai dengan Saragih (2001) bahwa adanya kalus belum tentu merupakan tanda bahwa stek dapat menghasilkan akar,

Tabel 5 Pengaruh Zat Pengatur Tumbuh (ZPT) terhadap berat basah akar, berat kering akar, dan berat basah tunas dari stek pucuk kayu putih (Melaleuca cajuputi) umur 4 bulan

\begin{tabular}{lccc}
\hline & \multicolumn{3}{c}{ Parameter } \\
\cline { 2 - 4 } Perlakuan ZPT & $\begin{array}{c}\text { Berat } \\
\text { basah } \\
\text { akar } \\
(\mathrm{gr})\end{array}$ & $\begin{array}{c}\text { Berat } \\
\text { kering } \\
\text { akar } \\
(\mathrm{gr})\end{array}$ & $\begin{array}{c}\text { Berat } \\
\text { basah } \\
\text { tunas } \\
(\mathrm{gr})\end{array}$ \\
\hline $\mathrm{A}_{1}$ (IBA 0 ppm) & 0.0037 & 0.0017 & 0.0045 \\
$\mathrm{~A}_{2}$ (IBA 500 ppm) & 0.0031 & 0.0018 & 0.0044 \\
$\mathrm{~A}_{3}$ (IBA 1500 ppm) & 0.0038 & 0.0015 & 0.0079 \\
\hline
\end{tabular}

karena fungsi kalus adalah untuk menutup luka dan mencegah pembusukan stek. Menurut Rochiman dan Harjadi (1973) stek yang terbentuk dari kalus jauh lebih baik daripada stek yang terbentuk tanpa terbentuk kalus terlebih dahulu.

Hasil analisis sidik ragam diketahui bahwa perlakuan ZPT dan media tanam tidak memberikan pengaruh nyata, baik secara tunggal maupun interaksi keduanya pada persentase berakar. Pertumbuhan akar baru pada stek dipengaruhi oleh ketersediaan hormon auksin pada bahan stek (Supriyanto dan Prakasa 2011), sehingga pemberian IBA harus dengan konsentrasi yang tepat. Hal ini sesuai dengan Salisbury dan Ross (1995) bahwa konsentrasi IBA bertahan pada tingkat yang tepat, khususnya pada tahap pembentukan akar selanjutnya.

Pembentukan tunas pada stek sangat penting untuk memproduksi auksin dan mentransfer auksin tersebut ke bawah yang berperan untuk menstimulir pembentukan akar sebelum stek layu dan akhirnya mati (Oboho dan Iyadi 2013). Persentase bertunas stek kayu putih secara kesuluruhan ialah $80.9 \%$ atau sebanyak 131 stek. Hasil analisis sidik ragam menunjukkan bahwa pemberian ZPT dan media tanam tidak berpengaruh nyata, baik secara tunggal maupun interaksi keduanya pada persentase bertunas. Perbedaan nilai persentase bertunas tidak terlalu signifikan, dengan rentang nilai $74.1 \%$ $85.4 \%$ pada perlakuan IBA berbagai konsentrasi. Hasil perlakuan berbagai media tanam juga tidak menunjukan perbedaan yang signifikan dengan rentang nilai persentase berakar adalah 79.6\%-81.7\%. Nilai ini menunjukkan pertumbuhan tunas yang tinggi. Hal ini diduga karena adanya peran auksin alami (endogen) dalam bahan stek. Auksin berperan penting dalam diferensiasi dan perpanjangan sel (Erdag et al. 2010). Auksin alami yang dihasilkan oleh tanaman mengubah cadangan karbohidrat menjadi gula larut yang sangat diperlukan untuk pembelahan sel serta meningkatkan mobilisasi gula dari daun ke pangkal stek untuk pembentukan primordia akar menjadi akar (Kurniawati dan Danu 2014).

\section{Berat Basah Akar, Berat Kering Akar, dan Berat Basah Tunas}

Berat basah pada akar menunjukkan besaran kandungan air yang terdapat dalam akar. Hasil analisis sidik ragam diketahui bahwa perlakuan ZPT dan media tanam tidak berpengaruh nyata, baik secara tunggal

Tabel 6 Pengaruh media tanam terhadap berat basah akar, berat kering akar, dan berat basah tunas dari stek pucuk kayu putih (Melaleuca cajuputi) umur 4 bulan

\begin{tabular}{lccc}
\hline & \multicolumn{3}{c}{ Parameter } \\
\cline { 2 - 4 } Perlakuan media & $\begin{array}{c}\text { Berat } \\
\text { basah } \\
\text { tanam }\end{array}$ & $\begin{array}{c}\text { Berat } \\
\text { kering } \\
\text { akar } \\
(\mathrm{gr})\end{array}$ & $\begin{array}{c}\text { Berat } \\
\text { basah } \\
\text { tunas } \\
(\mathrm{gr})\end{array}$ \\
\hline $\mathrm{A}_{1}$ (IBA 0 ppm) & 0.0052 & 0.0022 & 0.0046 \\
$\mathrm{~A}_{2}$ (IBA 500 ppm) & 0.0030 & 0.0016 & 0.0073 \\
$\mathrm{~A}_{3}$ (IBA 1500 ppm) & 0.0024 & 0.0013 & 0.0050 \\
\hline
\end{tabular}


maupun interaksi keduanya pada berat basah akar. Ratarata berat basah akar seluruh perlakuan adalah 0.0035 gr. Pengaruh ZPT dan pengaruh media tanam terhadap berat basah akar, berat kering akar, dan berat basah tunas dari stek pucuk kayu putih dapat dilihat pada Tabel 5 dan Tabel 6.

Kondisi akar yang tumbuh pada media tanam tanah tampak lebih lebih tipis dan runcing, diameter akar primer kecil, dan jumlah akar sekunder yang tumbuh sedikit. Kondisi perakaran pada media tanam pasir dan arang sekam minimum hara, sehingga proses fotosintesis menjadi sumber utama karbohidrat untuk pertumbuhan. Hal ini sesuai dengan Romdiana (2001) bahwa peranan media hanya berfungsi sebagai penegak tubuh stek dan pensuplai air saja, dan fungsinya sebagai penyedia hara bagi tanaman sangat kecil.

Rata-rata berat kering akar seluruh perlakuan adalah 0.0017 gr. Berat kering tanaman menggambarkan akumulasi senyawa organik yang berhasil disintesis tanaman dari senyawa anorganik (unsur hara, air, dan karbohidrat), semakin baik berat kering tanaman maka semakin baik pertumbuhan bibit (Putri dan Nurhasby 2010, Sofyan et al. 2014). Hasil analisis sidik ragam diketahui bahwa perlakuan IBA dan media tanam tidak berpengaruh nyata, baik secara tunggal maupun interaksi keduanya pada berat kering akar. Rentang nilai rata-rata berat kering akar tidak menunjukan perbedaan yang siginifikan, yaitu antara 0.0015 gr-0.0018 gr pada perlakuan IBA, dan pada perlakuan media tanam antara 0.0013 gr-0.0022 gr. Hasil ini menunjukkan bahwa pemberian IBA pada berbagai konsentrasi dan kombinasi media tanam tidak efektif dalam menunjang berat kering akar. Suatu tanaman akan tumbuh subur apabila segala unsur yang dibutuhkannya tersedia dan terdapat dalam bentuk yang sesuai untuk diserap tanaman (Supriyanto dan Fiona 2010).

Rata-rata berat basah tunas seluruh perlakuan adalah 0.0056 gr. Hasil analisis sidik ragam diketahui perlakuan ZPT dan media tanam tidak berpengaruh nyata, baik secara tunggal maupun interaksi keduanya pada berat basah tunas. Berat basah tunas pada perlakuan IBA 0 ppm, IBA 500 ppm, dan IBA 1500 ppm beruturut-turut adalah 0.0045 gr, 0.0044 gr, dan $0.0079 \mathrm{gr}$, dan berat basah tunas pada perlakuan media tanam tanah, pasir, serta pasir dan arang sekam berturutturut adalah 0.0046 gr, 0.0050 gr, dan 0.0073 gr. Tunas pada penelitian ini tumbuh lebih pesat dibandingkan akar stek. Hal ini terlihat dari total berat basah tunas 0.0056 gr lebih besar daripada total berat basah akar

Tabel 7 Pengaruh Zat Pengatur Tumbuh (ZPT) terhadap berat berat kering tunas, jumlah akar primer, dan jumlah akar sekunder dari stek pucuk kayu putih (Melaleuca cajuputi) umur 4 bulan

\begin{tabular}{lccc}
\hline & \multicolumn{3}{c}{ Parameter } \\
\cline { 2 - 4 } Perlakuan ZPT & $\begin{array}{c}\text { Berat } \\
\text { kering } \\
\text { tunas } \\
(\mathrm{gr})\end{array}$ & $\begin{array}{c}\text { Jumlah } \\
\text { akar } \\
\text { primer } \\
(\mathrm{n})\end{array}$ & $\begin{array}{c}\text { Jumlah akar } \\
\text { sekunder } \\
(\mathrm{n})\end{array}$ \\
\hline $\mathrm{A}_{1}$ (IBA 0 ppm) & 0.0037 & 2 & 8 \\
$\mathrm{~A}_{2}$ (IBA 500 ppm) & 0.0031 & 2 & 10 \\
$\mathrm{~A}_{3}$ (IBA 1500 ppm) & 0.0036 & 1 & 7 \\
\hline
\end{tabular}

0.0035 gr. Nilai persentase bertunas juga lebih tinggi daripada persentase berakar (Tabel 3 dan Tabel 4). Persentase bertunas ialah $80.9 \%$, sedangkan persentase berakar ialah $61.2 \%$. Rismunandar (1984) menyatakan bahwa pertumbuhan tunas yang lebih pesat pada stek daripada pertumbuhan akar menunjukkan kandungan protein lebih tinggi daripada kandungan karbohidrat, dan umumnya jika auksin tinggi maka sitokinin rendah, sehingga cenderung membentuk akar adventif. Jika auksin rendah maka sitokinin tinggi, dan cenderung membentuk tunas adventif.

\section{Berat Kering Tunas, Jumlah Akar Primer, dan Jumlah Akar Sekunder}

Berat kering tanaman digunakan untuk mengetahui baik atau tidaknya pertumbuhan suatu tanaman, karena variabel ini dapat menggambarkan efisiensi proses fisiologis di dalam tanaman (Wulandari dan Susanti 2012). Rata-rata berat kering tunas seluruh perlakuan adalah 0.0035 gr. Nilai ini lebih besar daripada total berat kering akar yaitu 0.0017 gr. Hasil analisis sidik ragam diketahui bahwa perlakuan ZPT dan media tanam tidak memberikan pengaruh nyata, baik secara tunggal maupun interaksi keduanya terhadap berat kering tunas. Hasil uji yang tidak berpengaruh nyata menunjukkan penggunaan IBA dengan berbagai konsentrasi memberikan hasil yang sama dengan tanpa menggunakan IBA. Hal yang sama juga diketahui pada faktor jenis media tanam, walaupun karakteristik masing-masing media tanam berbeda, namun tidak memberikan pengaruh yang siginifikan pada berat kering tunas. Rentang nilai berat kering tunas tidak menunjukkan perbedaan yang signifikan, yaitu antara 0,0031 gr-0.0037 gr pada perlakuan IBA, dan antara 0.0029 gr-0.0039 gr pada perlakuan media tanam.

Mekanisme pembentukan akar primer yaitu: auksin akan memperlambat timbulnya senyawa-senyawa dalam dinding sel yang berhubungan dengan pembentukan kalsium pekat, sehingga menyebabkan dinding sel menjadi lebih elastis (Hastuti 2002). Hasil analisis sidik ragam diketahui bahwa perlakuan ZPT dan media tanam tidak berpengaruh nyata, baik secara tunggal maupun interaksi keduanya terhadap jumlah akar primer pada selang kepercayaan 95\%. Hal ini terjadi karena semua jenis media tanam mendukung pengakaran stek. Menurut Rochiman dan Harjadi (1973), perbedaan jenis media tanam terhadap pembentukan akar tidak nyata selama media dapat memenuhi syarat-syarat pembentukan akar yaitu ringan, mempunyai komposisi

Tabel 8 Pengaruh media tanam terhadap berat berat kering tunas, jumlah akar primer, dan jumlah akar sekunder dari stek pucuk kayu putih (Melaleuca cajuputi) umur 4 bulan

\begin{tabular}{lccc}
\hline & \multicolumn{3}{c}{ Parameter } \\
\cline { 2 - 4 } $\begin{array}{l}\text { Perlakuan media } \\
\text { tanam }\end{array}$ & $\begin{array}{c}\text { Berat } \\
\text { kering } \\
\text { tunas } \\
(\mathrm{gr})\end{array}$ & $\begin{array}{c}\text { Jumlah } \\
\text { akar } \\
\text { primer } \\
(\mathrm{n})\end{array}$ & $\begin{array}{c}\text { Jumlah } \\
\text { akar } \\
\text { sekunder } \\
(\mathrm{n})\end{array}$ \\
\hline $\mathrm{A}_{1}$ (IBA 0 ppm) & 0.0039 & 1 & 7 \\
$\mathrm{~A}_{2}$ (IBA 500 ppm) & 0.0036 & 1 & 7 \\
$\mathrm{~A}_{3}$ (IBA 1500 ppm) & 0.0029 & 2 & 11 \\
\hline
\end{tabular}


yang seragam, mudah tersedia, mampu menyimpan air, dan bebas hama penyakit. Jumlah rata-rata akar primer yang tumbuh ialah 2 buah pada perlakuan IBA dan 1 buah pada perlakuan media tanam (Tabel 7 dan Tabel 8).

Konsentrasi IBA maksimum yang diperlukan oleh stek kayu putih ialah 1500 ppm. Hal ini terlihat dari rata-rata jumlah akar primer yang dihasilkan ialah 1 buah pada perlakuan IBA 1500 ppm (Tabel 7). Hasil ini lebih rendah dibandingkan dengan konsentrasi IBA 500 ppm dan 0 ppm dimana rata-rata jumlah akar primer ialah 2 buah. Kondisi diduga karena bahan stek mengandung karbohidrat sebagai cadangan makanan yang terbentuk dari proses fotosintesis. Cadangan makanan yang cukup pada bahan stek diperlukan untuk pembentukan akar (Supriyanto dan Prakasa 2011). Auksin yang diberikan pada stek dari jaringan tanaman yang masih muda dapat merangsang keluarnya akar, sedangkan pada akar yang sudah tua hanya bisa merangsang terjadinya pembelahan sel.

Jumlah akar menunjukkan kemampuan dalam penyerapan unsur hara (Rusmayasari 2006). Jumlah total rata-rata akar sekunder yang tumbuh adalah 8 buah baik pada perlakuan IBA maupun perlakuan media tanam. Berdasarkan hasil analisis ragam diketahui bahwa bahwa perlakuan ZPT dan media tanam tidak berpengaruh nyata, baik secara tunggal maupun interaksi keduanya pada jumlah akar sekunder, sehingga tidak perlu dilakukan uji lanjut Duncan. Akar sekunder tumbuh pada semua perlakuan (IBA 0 ppm, IBA 500 ppm, IBA 1500 ppm dan media tanam tanah, pasir, arang sekam dan pasir dengan perbedaan jumlah akar sekunder tidak terlalu signifikan, yaitu antara 7-11 buah akar (Tabel 7 dan Tabel 8). Karakteristik akar sekunder yang tumbuh pada media tanam arang sekam dan pasir lebih banyak terdapat akar sekunder dan diameter akar primer tampak lebih besar dan berisi, sehingga arang sekam dan pasir cocok digunakan sebagai media tanam stek pucuk.

Kondisi ini didukung oleh pemilihan bahan awal stek yang masih muda secara seragam yaitu bibit kayu putih umur 4 bulan. Hasil ini sesuai dengan Istomo et al. (2014) bahwa bibit yang masih muda (semai juvenile) memiliki kemampuan untuk melakukan perpanjangan sel yang pesat (fase juvenile). Pada dasarnya fase dewasa juga digunakan untuk reproduksi, namun kurang optimal untuk perbanyakan secara vegetatif (Riodevriza 2010). Hormon yang dihasilkan pucuk sebagian akan diangkut ke bagian basal stek melalui jaringan floem (Rusmayasari 2006). Akumulasi hormon

Tabel 9 Pengaruh Zat Pengatur Tumbuh (ZPT) terhadap panjang akar primer dan panjang tunas dari stek pucuk kayu putih (Melaleuca cajuputi) umur 4 bulan

\begin{tabular}{lcc}
\hline \multirow{2}{*}{ Perlakuan ZPT } & \multicolumn{2}{c}{ Parameter } \\
\cline { 2 - 3 } & $\begin{array}{c}\text { Panjang akar } \\
\text { primer }(\mathrm{cm})\end{array}$ & $\begin{array}{c}\text { Panjang } \\
\text { tunas (cm) }\end{array}$ \\
\hline $\mathrm{A}_{1}$ (IBA 0 ppm) & 2.1 & 2.5 \\
$\mathrm{~A}_{2}$ (IBA 500 ppm) & 2.0 & 2.1 \\
$\mathrm{~A}_{3}$ (IBA 1500 ppm) & 1.6 & 1.8 \\
\hline
\end{tabular}

tersebut menjadikan sel kambium lebih cepat membelah membentuk kalus yang selanjutnya berkembang menjadi akar (Rochiman dan Harjadi 1973).

\section{Panjang Akar Primer dan Panjang Tunas}

Panjang akar menunjukkan batas kemampuan tanaman untuk menjangkau wilayah tertentu dalam penyerapan unsur hara (Rusmayasari 2006). Parameter jumlah akar primer memperlihatkan kapasitas volume akar dari tanaman hasil stek pucuk (Moko 2004). Pengaruh ZPT dan pengaruh media tanam terhadap panjang akar primer dan panjang tunas dari stek pucuk kayu putih dapat dilihat pada Tabel 9 dan Tabel 10.

Rata-rata panjang akar primer pada perlakuan IBA berkisar antara $1.6 \mathrm{~cm}-2.1 \mathrm{~cm}$, dan pada perlakuan media tanam antara $1.9 \mathrm{~cm}-2.1 \mathrm{~cm}$. Perbedaan ini tidak terlalu signifikan, karena hasil analisis sidik ragam diketahui bahwa perlakuan ZPT dan media tanam tidak berpengaruh nyata, baik secara tunggal maupun interaksi keduanya pada panjang akar primer. Kondisi ini diduga karena karakteristik media tanam dan kandungan auksin pada bahan stek sudah cukup, sehingga memudahkan akar stek pucuk kayu putih dapat menembus media, dan daerah pemanjangan akar semakin besar serta dapat mempercepat proses pemanjangan akar. Hal ini sesuai dengan Khan et al. (2012), Negi et al. (2010) bahwa inisiasi akar adventif secara fisiologis dipengaruhi oleh kandungan auksin dalam jaringan. Kondisi nutrisi bahan stek dalam hal ini adalah keseimbangan antara karbohidrat dan nitrogen mempengaruhi keberhasilan perakaran stek, tetapi tidak dapat diperkirakan secara pasti nilai $\mathrm{C} / \mathrm{N}$ yang terbaik untuk perakaran stek suatu jenis tanaman.

Kehadiran tunas sangat penting terhadap proses inisiasi akar, karena akar juga sebagai tempat penghasil auksin yang akan ditranslokasikan ke dasar potongan stek dan diperlukan untuk difrensiasi sel (Hayati et al. 2012). Parameter pertumbuhan tunas bukan indikator yang dominan dalam penilaian keberhasilan stek karena pembentukan pucuk belum berarti terbentuk akar. Stek mampu melakukan pertumbuhan tunas, tetapi permukaaan dasar stek kadang-kadang sudah membusuk. Hasil analisis sidik ragam diketahui bahwa perlakuan ZPT dan komposisi IBA tidak berpengaruh nyata, baik secara tunggal maupun interaksi keduanya pada panjang tunas.

Perbedaan panjang tunas pada berbagai perlakuan tidak signifikan, hanya berkisar antara $1.8 \mathrm{~cm}-2.5 \mathrm{~cm}$ (Tabel 9 dan tabel 10). Pada minggu pertama hingga minggu ke dua tunas stek sudah banyak yang tumbuh, namun akar belum terbentuk. Hal ini diduga karena

Tabel 10 Pengaruh media tanam terhadap panjang akar primer dan panjang tunas dari stek pucuk kayu putih (Melaleuca cajuputi) umur 4 bulan

\begin{tabular}{lcc}
\hline \multirow{2}{*}{$\begin{array}{l}\text { Perlakuan media } \\
\text { tanam }\end{array}$} & \multicolumn{2}{c}{ Parameter } \\
\cline { 2 - 3 } & $\begin{array}{c}\text { Panjang akar } \\
\text { primer }(\mathrm{cm})\end{array}$ & $\begin{array}{c}\text { Panjang tunas } \\
(\mathrm{cm})\end{array}$ \\
\hline $\mathrm{A}_{1}$ (IBA 0 ppm) & 1.9 & 2.1 \\
$\mathrm{~A}_{2}$ (IBA 500 ppm) & 1.7 & 2.1 \\
$\mathrm{~A}_{3}$ (IBA 1500 ppm) & 2.1 & 2.3 \\
\hline
\end{tabular}


adanya pengaruh cahaya, di mana ujung batang tanaman selalu tumbuh menuju arah datangnya cahaya matahari. Bagian batang yang tidak terkena cahaya matahari akan mengalami pemanjangan, sedangkan bagian yang terkena sinar matahari tidak mengalami pemanjangan. Menurut Rochiman dan Harjadi (1973), cahaya mempunyai pengaruh merintangi pembentukan akar. Stek memiliki pengaturan intensitas dan durasi pencahayaan yang sesuai, karena intensitas cahaya yang diperlukan untuk fotosintesis tidak setinggi pada stek yang memiliki jaringan dan organ yang lengkap (Rusmayasari 2006).

\section{Prospek pengembangan stek pucuk kayu putih}

Hasil penelitian ini dengan persen keberhasilan stek tinggi (Tabel 3 dan Tabel 4) memberikan informasi penting untuk pemanfaatan stek pucuk kayu putih pada masa mendatang dalam mendukung pembangunan hutan tanaman kayu putih melalui perbanyakan secara vegetatif. Stek kayu putih dapat memperpendek waktu produksi bibit di persemaian menjadi 2-3 bulan, sedangkan rata-rata waktu produksi bibit kayu putih melalui benih di persemaian PT Bukit Asam (Persero), Tbk sampai siap tanam di lapangan ialah 6 bulan. Mengandalkan tanaman kayu putih hanya dari benih saja (perbanyakan generatif) tidak menjamin tanaman bisa tumbuh unggul dari generasi ke generasi, walaupun asal induknya berasal dari individu unggul, sehingga stek pucuk merupakan alternatif tepat dalam perbanyakan tanaman.

Sifat arang sekam yang mampu mempertahankan kelembapan baik digunakan untuk media tanam stek, dengan kombinasi media tanam pasir. Penggunaan stek pucuk diprioritaskan pada pohon-pohon unggul yang memiliki rendeman tinggi dan kadar cinole 1.8 yang tinggi, sebab perbanyakan stek pucuk ini membawa sifat genetik yang dimiliki induknya. PT Bukit Asam (Persero), Tbk dapat mengadopsi perbanyakan tanaman kayu putih dengan teknik stek pucuk untuk memenuhi kebutuhan bibit yang akan ditanam di areal revegetasi. Kebutuhan bibit ini dapat dipenuhi dengan kualitas sifat genetik bibit dari hasil stek yang sama dengan induknya, serta mendukung produksi minyak kayu putih yang dilakukan PT Bukit Asam (Persero), Tbk.

\section{SIMPULAN}

Kayu putih dapat diperbanyak secara vegetatif melalui stek pucuk. Perlakuan pemberian ZPT IBA dan media tanam tidak memberikan pengaruh nyata, baik secara tunggal maupun interaksi keduanya pada persentase hidup, persentase berakar, persentase bertunas, berat basah akar, berat kering akar, berat basah tunas, berat kering tunas, jumlah akar primer, jumlah akar sekunder, panjang akar primer, dan panjang tunas kayu putih. Oleh karena itu, stek pucuk dapat dilakukan tanpa ZPT IBA dengan hasil persentase hidup, persentase berakar, persentase bertunas berturutturut $88.9 \%, 61.2 \%$, dan $80.9 \%$.

\section{DAFTAR PUSTAKA}

Demastiti K. 2015. Stek pucuk Binuang Bini (Octomeles sumatrana Miq.) dengan perlakuan media tanam dan pemberian Zat Pengatur Tumbuh [skripsi]. Bogor (ID): Institut Pertanian Bogor.

Erdag BB, Emek YC, Aydogan SK. 2010. Clonal propagation of Dorystoechas hastata via axillary shoot proliferation. Turk Journal Botani. 34: 233240.

Fitria FQ. 2015. Pembiakan Saninten (Castanopsis argentea (Blume) A.dc.) melalui stek pucuk dengan Zat Pengatur Tumbuh komersial [skripsi]. Bogor (ID): Institut Pertanian Bogor.

Hayati E, Sabaruddin, Rahmawati. 2012. Pengaruh jumlah mata tunas dan komposisi media tanam terhadap pertumbuhan stek tanaman Jarak Pagar (Jatrophacurcas L.). Jurnal Agrista. 16(3): 131132.

Hastuti ED. 2002. Fitohormon Laboratorium Biologi Struktur dan Fungsi Tumbuhan. Semarang (ID): Universitas Diponegoro.

Istomo, Atok S, Susilo R. 2014. Pengaruh asal bahan dan media stek terhadap keberhasilan stek pucuk Tembesu Fagraea fragrans (Roxb.). Jurnal Berita Biologi. 13(3): 275-281.

Kartikawati NK, Rimbawanto A. 2010. Potensi Pengembangan Industri Minyak Kayu Putih. Bogor (ID): Departemen Kehutanan Badan Penelitian dan Pengembangan Kehutanan.

Khan FU, Khan GS, Siddiqui T, Khan SH. 2012. Effect of indole butyric acid (growth hormone) on possibility of raising Dalbergia sissoo through branch cuttings. International Journal of Pharmacy and Biological Science. 2(3): 33-36.

Kurniawati PP, Danu. 2014. Pengaruh umur bahan stek dan Zat Pengatur Tumbuh terhadap keberhasilan stek Kemenyan (Styrax benzoin Dryand). Jurnal Penelitian Hutan Tanaman. 11(3): 144-145.

Matjik AA, Sumertajaya IM. 2006. Perancangan Percobaan dengan Aplikasi SAS dan Minitab. Bogor (ID): IPB Press.

Negi S, Sukumar P, Liu X, Cohen JD, Muday GK. 2010. Genetic dissection of the role of ethylene in regulating auxin-dependent lateral and adventitious root formation in tomato. Plant Journal. 6: 315.

Nurzaman Z. 2005. Pengaruh Zat Pengatur Tumbuh NAA dan IBA terhadap pertumbuhan stek Mini Pule Pandak (Rauwolfia serpentina Benth.) hasil kultur in vitro pada media arang sekam dan zeolit [skripsi]. Bogor (ID): Institut Pertanian Bogor.

Oboho EG \& Iyadi JN. 2013. Rooting potential of mature stem cuttings of some forest tree species for vegetative propagation. Journal of Applied and Natural Science. 5(2): 442-446.

Presiden Republik Indonesia. 2008. Peraturan Pemerintah Republik Indonesia Nomor 76 Tahun 2008 tentang Rehabilitasi dan Reklamasi Hutan. Jakarta (ID): RI.

Putri KP, Nurhasby. 2010. Pengaruh jenis media organik terhadap kualitas bibit Takir (Duabanga 
moluccana). Jurnal Penelitian Hutan Tanaman. 7(3): 141-145.

Priadjati AGW, Tolkamp. 2002. Metode Pembuatan Stek Dipterocarpaceae. Manual Persemaian Dipterocarpaceae. Badan Penelitian dan Pengembangan Departemen Kehutanan. 4: 1-19.

Riodevriza. 2010. Pengaruh pohon induk terhadap keberhasilan stek dan sambungan Shorea selanica BL. [skripsi]. Bogor (ID): Institut Pertanian Bogor.

Rismunandar. 1984. Liku-Liku Bertanam Anggur. Bandung (ID): Sinar Baru.

Rochiman K, Harjadi SS. 1973. Pembiakan Vegetatif. Bogor (ID): Departemen Agronomi Fakultas Pertanian IPB.

Romdiana D. 2001. Pengaruh pemberian Zat Pengatur Tumbuh dan jenis media terhadap pertumbuhan stek pucuk Benuang Bini (Octomeles sumatrana Miq.) [skripsi]. Bogor (ID): Institut Pertanian Bogor.

Saragih LM. 2001. Pengaruh intensitas naungan dan Zat Pengatur Tumbuh IBA terhadap pertumbuhan stek pucuk Shorea selanica BL. [skripsi]. Bogor (ID): Institut Pertanian Bogor.
Salisbury FB, Ross CW. 1995. Plant Physiology 3rd Ed. California (US): Warworth Publishing Company Belmonth.

Supriyanto, Fiona F. 2010. Pemanfatan arang sekam untuk memperbaiki pertumbuhan semai Jabon (Anthocephalus cadamba (Roxb.) Miq) pada media subsoil. Jurnal Silvikultur Tropika. 1(1):2428.

Supriyanto, Prakarsa KE. 2011. Pengaruh Zat Pengatur Tumbuh Rootone-F terhadap pertumbuhan stek Duabanga moluccana. Blume. Jurnal Silvikultur Tropika. 3(1): 59-65.

Wulandari AS, Susanti S. 2012. Aplikasi pupuk daun organik untuk meningkatkan pertumbuhan bibit jabon (Anthocephalus cadamba Roxb. Miq). Jurnal Silvikultur Tropika. 3(2):137-142. 